REFERENCES AND NOTES

1. Anderson, B., Hoffman, P., and Meyer, K.: The $O$-serine linkage in peptides of chondroitin 4- or 6-sulfate. J. Biol. Chem., 240: 156 (1965)

2. Bezkorovainy, A.: Some physical and chemical properties of an M-2 glycoprotein isolated from normal bovine plasma. Biochemistry, 2: 10 (1963).

3. Bezkorovainy, A.: Comparative study of the acid glycoproteins isolated from bovine serum, colostrum, and milk whey. Arch. Biochem. Biophys., 110: 558 (1965).

4. Bezkorovainy, A., and Doherty, D. G.: Isolation and characterization of an acidic glycoprotein from normal bovine plasma. Arch. Biochem. Biophys., 96: 491 (1962).

5. Bezkorovainy, A., and Winzler, R. J.: Isolation and characterization of an acidic $\alpha_{2}$-glycoprotein. Biochim. Biophys. Acta, 49: 559 (1961).

6. Cheron, A.: Les globulines immunes de lait. Ann. Nutr. Alim., 25: A135-A179 (1971).

7. Dubois, M., Gilles, K. A., Hamilton, J. K., Rebers, P. A., and Smith, M.: A colorimetric method for determination of sugars and related substances. Anal. Chem., 28: 350 (1956).

8. Goldman, A. S., and Smith, C. W.: Host resistance factors in human milk, J. Pediat., 82: 1082 (1973)

9. György, P.: A hitherto unrecognized biochemical difference between human milk and cow's milk. Pediatrics, $11: 98$ (1953).

10. György, P., Jeanloz, R. W., von Nicolai, H., and Zilliken, F.: Undialyzable growth factors for Lactobacillus bifidus var. pennsylvanicus. Eur. J. Biochem., 43: 29 (1974)

11. Hanson, L. §., and Johansson, B. G.: Immunological studies of human milk. In H. A. McKenzie: Milk Proteins, Vol. 1, p. 65 (Academic Press, New York, 1970)

12. Hirano, S., Hayashi, H., Terabayashi, T., Onodera, K., Iseki, S., Kochibe, N. Nagai, Y., Yagi, N., Nakagaki, T., and Imagawa, T.: Biologically active glycopeptides in human colostrum. J. Biochem., 64: 563 (1968),

13. Malpress, F. H., and Seid-Akhavan, M.: Studies on human $\alpha_{\mathbf{s}^{-}}$and $\kappa$-casein

Copyright (c) 1976 International Pediatric Research Foundation, Inc. fractions and human caseinoglycomacropeptide. Biochem. J., 101:764 (1966).

14. Nichols, J. H., and Bezkorovainy, A.: Isolation and characterization of a glycoprotein from human colostrum. Biochem. J., 135: 875 (1973).

15. Nichols, J. H., Bezkorovainy, A., and Landau, W.: Human colostral whey M-1 glycoproteins and their $L$. bifidus var. Penn. growth promoting activities. Life Sci., 14: 967 (1974)

16. Querinjean, P., Masson, P. I., and Heremans, F.: Molecular weight, single chain structure, and amino acid composition of human lactoferrin. Eur. J. Biochem. 20: 420 (1971).

17. Schachman, H. K.: Ultracentrifugation, diffusion, and viscometry. Methods Enzymol., 4: 32 (1957).

18. Winzler, R. J.: Determination of serum glycoproteins. Methods Biochem. Anal., 2: 279 (1955).

19. Zschocke, R., and Bezkorovainy, A.: Some immunochemical properties of succinylated human transferrin and related proteins. Biochim. Biophys. Acta, 200: 241 (1970)

20. Zschocke, R., Grieble, H. G., Bach, G. I., and Anderson, T. O.: Studies on IgA I. Fractionation procedure for isolation of $\mathrm{IgA}$ from pooled normal human plasma. J. Immunol., 102: 625 (1969).

21. Los Angeles, Calif

22. Piscataway, N. J.

23. St. Louis, Mo.

24. Detroit, Mich

25. Chicago, Ill.

26. This work was supported by Grant no. HD-05657-03 from the National Institutes of Health, United States Public Health Service. Many thanks due to $C P$ for her generous milk donations and to the Evanston Hospital Milk Bank (c/o Department of Pediatrics) for their fine cooperation.

27. Requests for reprints should be addressed to: A Bezkorovainy, Ph.D., Depart ment of Biochemistry, Rush-Presbyterian-St. Luke's Medical Center, Chicago, I11. 60612 (USA).

28. Accepted for publication July 10, 1975

Printed in U.S.A.

Pediat. Res. 10: 5-10 (1976)

Decanoic acid

fatty acids

hexanoic acid placenta protein binding

\title{
Transfer across Perfused Human Placenta. IV. Effect of Protein Binding on Free Fatty Acids
}

\author{
JOSEPH DANCIS, ${ }^{(16)}$ VALERIE JANSEN, AND MORTIMER LEVITZ \\ Departments of Pediatrics and Obstetrics and Gynecology, New York University School of Medicine, New York,
} New York, USA

\section{Extract}

The effect of protein binding on the rate of placental transfer of hexanoic ( $\mathrm{C} \mathrm{6}$ ) and decanoic ( $\mathrm{C} \mathrm{10}$ ) acids was investigated in an in vitro perfusion system of human placenta. As much as $30 \%$ of transferred $\mathrm{C} 6$ was converted to more polar compounds, so that the observations related to the combined effects on transfer and metabolism. Less than $10 \%$ of $\mathrm{C} 10$ was similarly metabolized. Both fatty acids are soluble in buffered salt solutions at the concentrations used $(40 \mu \mathrm{M})$ and both are bound to serum albumin, $C-10$ having higher association constants $\left(K^{\prime}\right.$ for $C 6,1.48 \times 10^{4}$; for $\left.\mathrm{C} 10,1.03 \times 10^{5}\right)$. When the placenta is perfused with buffered salt solution, the transfer of $\mathrm{C} 6$ is $22 \%$ more rapid than that of $\mathrm{C}$ 10. It is suggested that binding within the placenta retards $C 10$ more than $C 6$. The addition of $1 \mathrm{~g} / 100 \mathrm{ml}$ bovine serum albumin to the maternal perfusate reduces the transfer rate of $\mathrm{C} \mathbf{1 0}$ by $\mathbf{8 0 \%}$, whereas $2 \mathrm{~g} / 100 \mathrm{ml}$ serum albumin has a more moderate effect on $\mathrm{C}$ 6 (a reduction of $50 \%$ ). The addition of $1 \mathrm{~g} / 100 \mathrm{ml}$ serum albumin to the fetal perfusate increases transfer rate of both free fatty acids (FFA), C 6 by about $25 \%$ and C 10 by about $250 \%$. With equiva- lent concentrations of serum albumin in maternal and fetal perfusates, the transfer rate of $\mathrm{C} 10$ was reduced by $65 \%$, whereas there was no detectable effect on transfer of $\mathrm{C} 6$ in two of three experiments.

The transfer rates of FFA increase logarithmically with progressive shortening of the carbon chain from $\mathrm{C} 16$ to $\mathrm{C} 8$ when maternal and fetal perfusates contain serum albumin. Protein binding is apparently the determining factor. The rate of transfer falls off at $\mathrm{C}$ 6 and $\mathrm{C} \mathrm{4}$, even though protein-binding continues to decrease. The determining factor may be the hydrophilic nature of these molecules.

\section{Speculation}

If the observations on FFA have general applicability, the overall effect of protein binding on placental transfer of a particular substance may relate to its water solubility and protein binding. If water solubility is not a limiting factor, protein binding may decrease transfer rate sharply, as occurs with decanoic acid (C 10). With substances that have very limited water solubility, protein 
binding may increase transfer by increasing the amount presented to the placenta. Palmitic acid ( $\mathrm{C}$ 16) appears to be such a compound. The fraction bound to proteins in the perfusate, as measured by equilibrium dialysis, may not be the most significant factor determining rates of transfer. More significant may be the competitive aspects of binding in the perfusate and to the placenta in influencing rates of release and uptake.

It has been reported previously (2) that the transfer rate of FFA across perfused human placenta increases logarithmically with progressive shortening of the carbon chain. Several major changes in chemical characteristics are introduced by such alterations of the molecule, among them molecular size, lipid solubility, and protein binding. For reasons presented in the previous report, it appeared likely that protein binding exerted the most significant influence. Protein binding can affect transfer rates at three sites: by binding to albumin in the "maternal" perfusate, during transit through the placenta, and by binding to albumin in the "fetal" perfusate. The recent development of a technique for perfusing human placental in vitro (2) has made it possible to systemically investigate these possibilities.

The concentration of albumin in each circulation has been varied independently and the effects on the transfer rates of medium chain FFA and hexanoic ( $C$ 6) and ecanoic (C 10) acids have been measured. The medium chain FFA offer the technical advantages of being soluble in simple buffer perfusates at the concentrations used and of being protein bound when albumin is added, greatly facilitating the design of experiments. In addition, the association constants of $\mathrm{C} 10$ for albumin are higher than those of $\mathrm{C} 6$, providing information on the possible effect of that characteristic on transfer rates. These considerations outweighed the disadvantage that these medium chain FFA are not normally found in maternal plasma in nutritionally significant concentrations.

\section{METHODS}

\section{PERFUSION TECHNIQUE}

Placentas were obtained immediately after uncomplicated delivery per vaginam or by cesarian and placed in a basin of chilled Earle's buffered salt solution. The cesarians were elective, performed because of previous hysterotomy. A cotyledon was selected and the tributary fetal artery and vein cannulated and perfused with buffered salt solution, equilibrated previously with $95 \%$ $\mathrm{O}_{2}-5 \% \quad \mathrm{CO}_{2}$. The perfused cotyledon was separated from the remaining placenta and a second circulation started through small glass cannulas inserted into the intervillous space. The finished preparation consisted of a "maternal" and "fetal" circulation perfusing the intact "placental membrane." The details of the preparatory procedure have been described (6).

The substances under study were added to the maternal circulations, and the rates of appearance in the fetal perfusate were determined. Radioactive antipyrine was added routinely to provide a baseline for evaluating the clearances of the test substances. Both maternal and fetal circuits were kept "open," that is, the perfusates were not recirculated. The measurement of transfer rates were therefore not complicated by transfer of materials from the fetal circulation back into the maternal circulation. The experimental period generally lasted $30-45 \mathrm{~min}$, with each phase of the study lasting 15-20 min. A series of fetal samples were collected to ascertain stability of transfer rate.

Clearances were calculated by dividing the product of fetal concentration and flow rate by maternal concentration. The transfer rates of the FFA are presented relative to the clearance of antipyrine determined in the same experiment (see below). Each study was performed on a different placenta.
Clearance ratio (FFA to antipyrine)

$$
\begin{aligned}
& =\frac{\left[(\mathrm{FFA})_{\mathrm{Fv}} \times \mathrm{FFR}\right] /\left[(\mathrm{FFA})_{\mathrm{Ma}}\right]}{\left[(\mathrm{AP})_{\mathrm{Fv}}^{\cdot} \times \mathrm{FFR}\right] /\left[(\mathrm{AP})_{\mathrm{Ma}}\right]} \\
& =\frac{(\mathrm{FFA})_{\mathrm{Fv}} \times(\mathrm{AP})_{\mathrm{Ma}}}{(\mathrm{FFA})_{\mathrm{Ma}} \times(\mathrm{AP})_{\mathrm{Fv}}}
\end{aligned}
$$

in which $(\mathrm{FFA})=$ concentration of free fatty acid; (AP) = concentration of antipyrine; FFR = flow rate in fetal circuit; Fv = fetal "vein" (outflow); and $\mathrm{Ma}=$ maternal "artery" (inflow).

\section{PERFUSATES}

The basic perfusate was Earle's buffered salt solution to which fat-free bovine serum albumin (BSA) was added as indicated.

The fatty acids were dissolved in a small amount of ethanol with an appropriate amount of radioactive tracer, and added to the maternal perfusate in an amount to provide a concentration of 40 $\boldsymbol{\mu} \mathrm{M}$. This was done $12 \mathrm{hr}$ before the experiment to permit equilibration with albumin.

\section{SOLUBILITY IN ORGANIC SOLVENTS}

The partition of FFA between Earle's buffer and the organic solvents, toluene and hexane, was determined. A trace amount of radioactive FFA was blown to dryness with nitrogen in a test tube. One milliliter water and $1 \mathrm{ml}$ organic solvent were added to the tube and mixed on a vortex agitator and then centrifuged. One-half milliliter of each layer was transferred to Diotol and the radioactivity determined. Results are reported as the ratio of the activity in the organic solvent to that in the buffer. To minimize the effect of minor radioactive contaminants, serial extractions were done until a constant partition was achieved.

\section{EQUILIBRIUM DIALYSIS}

Dialysis tubing, 0.25 inch, was soaked in deionized water for 3 days before use. Dialysis bags were made containing $0.5 \mathrm{ml}$ BSA 1 $\mathrm{g} / 100 \mathrm{ml}$ or $2 \mathrm{~g} / 100 \mathrm{ml}$ in Earle's buffered salt solution or the salt solutions alone. Krebs-Ringer phosphate buffer, calcium free, was used for the study of C 10 . The bags were placed in 10-ml screw top vials containing $6 \mathrm{ml}$ radioactive FFA, $40 \mu \mathrm{M}$. The vials were incubated in a water bath with shaking for $24 \mathrm{hr}$ at $37^{\circ}$ at pH 7.4. The dialysis bags were removed and contents emptied into small tubes. The concentration of radioactivity inside and outside the bag was determined and protein binding calculated as follows

$$
\frac{\text { counts } / \mathrm{min} / \mathrm{ml} \text { inside bag }- \text { counts } / \mathrm{min} / \mathrm{ml} \text { outside bag }}{\text { counts } / \mathrm{min} / \mathrm{ml} \text { inside bag }} \times 100
$$

\section{IDENTIFICATION OF PERFUSED COMPOUNDS}

The $\mathrm{pH}$ of an aliquot of perfusate was raised to 9 by the dropwise addition of carbonate buffer, $\mathrm{pH}$ 10.4. The solution was extracted twice with chloroform. The $\mathrm{pH}$ of water phase was reduced to 2 by addition of $1 \mathrm{~N} \mathrm{HCl}$ and re-extracted twice with chloroform. The water phase was assayed for radioactivity. To the chloroform phase was added 1 drop concentrated $\mathrm{NH}_{4} \mathrm{OH}$ to reduce the volatility of the FFA, and the sample was blown to dryness with $\mathrm{N}_{2}$. The residue was redissolved in methanol and submitted to ascending chromatography in the solvent system; $\mathrm{N}$-butanol- $\mathrm{H}_{2} \mathrm{O}$-concentrated $\mathrm{NH}_{4} \mathrm{OH}(14: 2: 1)$. The solvents were permitted to ascend for $30 \mathrm{~cm}$. The strip was air-dried, cut into $1.2-\mathrm{cm}$ sections, and transferred to scintillant to determine radioactivity. Under these conditions, the $R_{F}$ values of $C 4, C 6$, and $C$ 10 were, respectively, $0.30,0.50$, and 0.66 .

\section{MATERIALS}

Fatty acids were obtained from Applied Science Laboratories (10). The radioactive compounds were purchased from New 
England Nuclear (11). The specific activities were: $\left[1{ }^{14} \mathrm{C}\right]$ sodium butyrate, $12.7 \mathrm{mCi} / \mathrm{mmol} ;\left[1-{ }^{14} \mathrm{C}\right]$ sodium hexanoate, $1.94 \mathrm{mCi} /$ mmol; $\left[1-{ }^{14} \mathrm{C}\right]$ decanoic acid, $10 \mathrm{mCi} / \mathrm{mmol}$; antipyrine- $N-\left[{ }^{3} \mathrm{H}\right]-$ methyl, $170 \mathrm{mCi} / \mathrm{mmol}$. Bovine albumin, fatty acid free, type $\mathrm{F}$ $(<0.005 \%)$ was obtained from Sigma Chemical Company (12).

\section{RADIOACTIVITY}

Radioactivity was determined in a two-channel scintillation spectrometer by adding $0.5 \mathrm{ml}$ perfusate to $10 \mathrm{ml}$ Diotol scintillant.

\section{RESULTS}

\section{PLACENTAL PERMEABILITY}

The transfer rates of $\mathrm{C} 6$ and $\mathrm{C} 10$ were determined with both the maternal and fetal sides of the placental perfused with buffered salt solution. Protein binding within the circulation was therefore eliminated. The transfer rate of $C 6$, as compared with antipyrine, was $0.77 \pm 0.04$ SEM (five experiments); of $\mathrm{C} 10,0.63 \pm 0.04$. The transfer rate of C 10 was consistently lower than that of C 6 . Results are the average of three samples at 5-min intervals. Variation around the mean was less than $5 \%$.

\section{PROTEIN BINDING IN MATERNAL CIRCULATION}

Each experiment consisted of two phases. The transfer rates were first determined with the placenta perfused with buffered salts. In the second part of the experiment, the FFA was circulated through the maternal side of the placenta in buffered salts containing 1 or $2 \mathrm{~g} / 100 \mathrm{ml}$ BSA (Table 1 ).

The addition of $1 \mathrm{~g} / 100 \mathrm{ml}$ BSA to the maternal perfusate drastically reduces the transfer rate of C $10(81 \%$ and $84 \%)$ whereas $2 \mathrm{~g} / 100 \mathrm{ml} \mathrm{BSA}$ has a more moderate effect on C $6(55 \%$ and $50 \%$, consistent with the differences in the effectiveness of protein binding as measured by equilibrium dialysis.

\section{PROTEIN BINDING IN FETAL CIRCULATION}

The FFA were added to buffered salts in the maternal perfusate and the transfer rate determined when the fetal perfusate contained BSA. To exclude the possibility that the sequence of the perfusing

Table 1. Maternal-fetal transfer of hexanoic $(C 6)$ and decanoic $(C$ 10) acids: effect of bovine serum albumin (BSA) in maternal perfusate

\begin{tabular}{cccc}
\hline & Buffered salts & BSA & $\begin{array}{c}\text { \% Protein } \\
\text { bound }^{2}\end{array}$ \\
\hline $\mathrm{C} 6$ & & & \\
1 & 0.69 & $0.51^{3}$ & 74 \\
2 & 0.84 & $0.42^{3}$ & \\
$\mathrm{C} 10$ & 0.43 & $0.08^{4}$ & 93 \\
3 & 0.63 & $0.10^{4}$ & \\
4 & & & \\
\hline
\end{tabular}

${ }^{1}$ Four experiments were done, each with a different placenta. Each experiment consisted of two phases: in the first, buffered salts were used as maternal and fetal perfusate, in the second phase, BSA was added to the maternal perfusate. Transfer rate in this, and all subsequent tables, is expressed as the ratio of clearance of FFA to clearance of antipyrine. Clearances were calculated from the average of three fetal samples collected at 5-min intervals. Variation of sample was less than 5\% around the mean, indicating a stable rate of transfer. Clearance of $\mathrm{C} 6$ includes transfer of $\mathrm{C} 6$ and radioactive metabolites.

${ }^{2}$ Protein binding as determined by equilibrium dialysis.

${ }^{3} \mathrm{BSA}, 2 \mathrm{~g} / 100 \mathrm{ml}$ in buffered salts.

${ }^{4} \mathrm{BSA}$, in $1 \mathrm{~g} / 100 \mathrm{ml}$ in buffered salts.
Table 2. Maternal-fetal transfer of hexanoic $(C 6)$ and decanoic (C 10) acids: effect of bovine serum albumin $(B S A)$ in fetal perfusate ${ }^{1}$

\begin{tabular}{ccccc}
\hline & Buffer & $\begin{array}{c}0.05 \mathrm{~g} / 100 \mathrm{ml} \\
\text { BSA }\end{array}$ & $\begin{array}{c}1 \mathrm{~g} / 100 \mathrm{ml} \\
\text { BSA }\end{array}$ & Buffer \\
\hline C6 & & & & \\
1 & 0.77 & 0.80 & 0.95 & \\
2 & & & 1.28 & 0.92 \\
C 10 & & & & \\
3 & 0.56 & 1.05 & 1.95 & 0.82 \\
4 & & & 2.71 & 0.92 \\
\hline
\end{tabular}

${ }^{1}$ The maternal perfusate in all four experiments consisted of buffered salt solution with a radioactive free fatty acid. The fetal perfusate was buffered salt solution with or without BSA, in the sequence indicated. BSA in fetal perfusate increases transfer rate. Transfer rate of free fatty acid may exceed that of antipyrine (ratio greater than 1.00 ).

Table 3. Maternal-fetal transfer of hexanoic $(C 6)$ and decanoic (C 10) acids: with bovine serum albumin $(B S A)$ in maternal and fetal perfusates ${ }^{1}$

\begin{tabular}{cccc}
\hline \multicolumn{3}{c}{ Perfusates } \\
\cline { 2 - 3 } & Buffer & 1\% BSA & Buffer \\
\hline C6 & & & \\
1 & 0.87 & 0.83 & 0.83 \\
2 & & 0.50 & 0.85 \\
3 & & 0.88 & 0.80 \\
C 10 & 0.66 & 0.25 & 0.73 \\
4 & & 0.29 & 0.71 \\
5 & & & \\
\hline
\end{tabular}

${ }^{1}$ Transfer rates were measured when the perfusates consisted of buffered salt solution and when $1 \mathrm{~g} / 100 \mathrm{ml}$ BSA was added to both maternal and fetal perfusates. Transfer rate of $\mathrm{C} 10$ is reduced with equivalent concentrations in both perfusates; with $\mathrm{C} 6$, there was no detectable effect in two of three experiments.

solutions in the fetal circulation affected the results, the sequence was reversed in some experiments.

BSA in the fetal perfusate increases the transfer rate of FFA (Table 2). The effect is greater with higher concentrations of BSA, and greater with $C 10$ than $C 6$, consistent with more effective protein binding. With $1 \mathrm{~g} / 100 \mathrm{ml} \mathrm{BSA}$ in the fetal perfusate, the increase in transfer rates for C 6 were $29 \%$ and $25 \%$; for C $10,250 \%$ and $230 \%$. Under these conditions, the transfer rate may exceed that of antipyrine (ratio greater than 1).

\section{PROTEIN BINDING IN MATERNAL AND FETAL CIRCULATIONS}

In vivo the concentration of serum albumin in the fetal circulation approximates that in the mother. The question arose as to whether the reduction in transfer rate exerted by protein binding in the maternal circulation is cancelled by the effect of albumin in the fetal circulation.

The maternal and fetal sides of the placenta were perfused with buffered salt solution, with and without BSA (Table 3). With C 6 , the relatively small restraining effect of $1 \mathrm{~g} / 100 \mathrm{ml} B S A$ in the maternal circulation was eliminated in two of three experiments when an equivalent concentration of BSA was added to the fetal perfusate. With C 10, the transfer rate was reduced $65 \%$ with BSA in both maternal and fetal perfusates, as compared with approximately $80 \%$ with BSA in the maternal perfusate only. 


\section{RELATION OF TRANSFER RATE TO LIPID SOLUBILITY AND} PROTEIN BINDING

The transfer rates of a series of FFA have been reported previously (2). The observations have now been extended from $\mathrm{C}$ 16 (palmitic acid) to $\mathrm{C} 4$ (butyric acid). In these experiments, maternal and fetal perfusates contained $1 \mathrm{~g} / 100 \mathrm{ml} \mathrm{BSA}$, except for a few experiments with $1 \mathrm{~g} / 100 \mathrm{ml}$ human serum albumin.

There is a logarithmic increase in transfer rate with progressive shortening of the carbon chain of the FFA, from $\mathrm{C} 16$ to $\mathrm{C} 8$. The curve begins to flatten at $C 6$, and transfer rate falls slightly at $C 4$ (Fig. 1). The relation of transfer rates to lipid solubility and to protein binding is presented in Table 4.

\section{IDENTIFICATION OF TRANSFERRED RADIOACTIVE MATERIALS}

The radioactivity in the fetal perfusate was further analyzed in representative experiments. The perfusates were extracted sequentially with chloroform at $\mathrm{pH} 9$ and $\mathrm{pH} 2$. In the experiment with buffered salt solution, 30\% of the radioactivity of $\mathrm{C} 6$ remained in the water phase at $\mathrm{pH} 2$, indicating extensive conversion to more polar metabolites. In the BSA experiment, the corresponding figure was $10 \%$. With $\mathrm{C} 10,99 \%$ of the radioactivity remained soluble in chloroform at $\mathrm{pH}$ 2. Paper chromatography of the chloroform fractions of C 6 and $\mathrm{C} 10$ demonstrated that $90 \%$ of the radioactivity had $R_{F}$ values appropriate for the specific FFA.

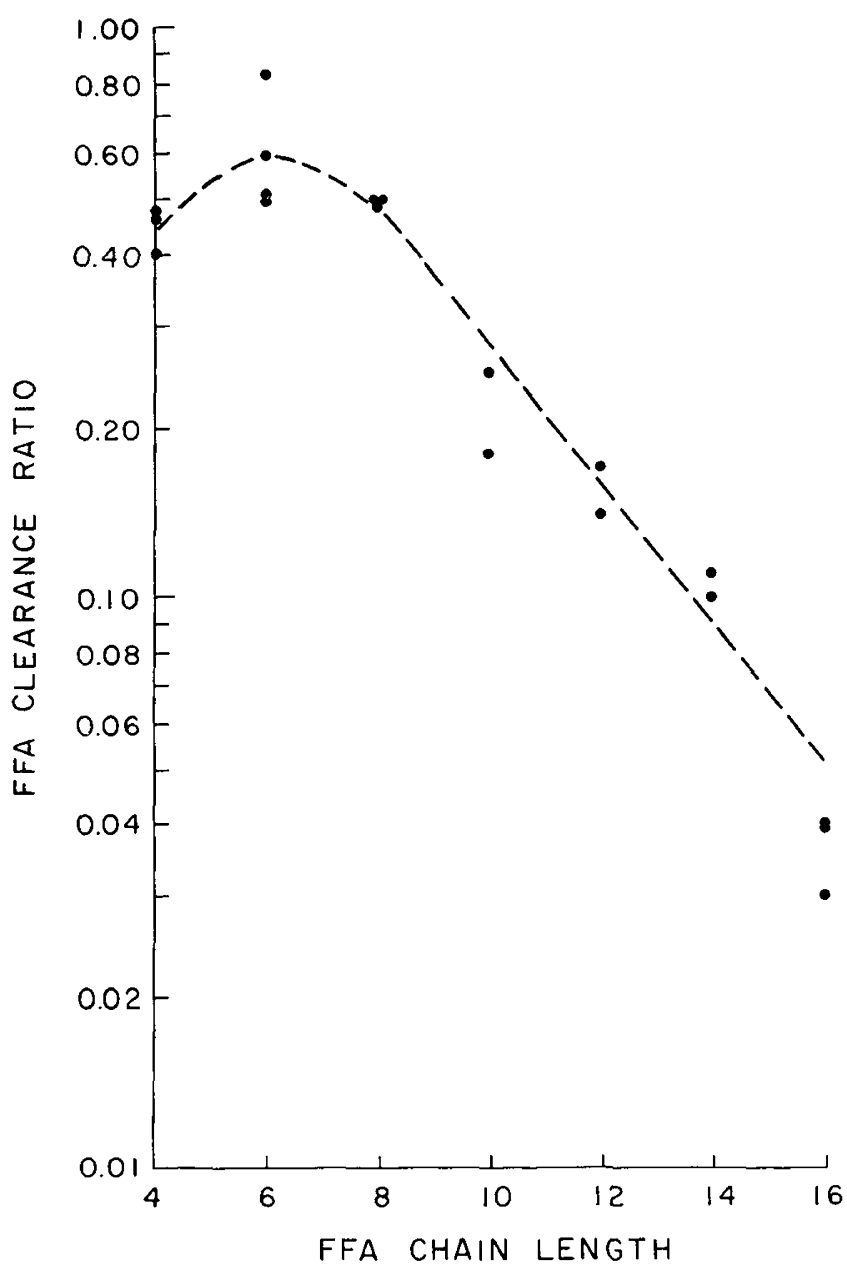

Fig. 1. Relation of clearance of free fatty acids $(F F A)$ to chain length. Placenta was perfused in a series of experiments with buffered salt solution containing $1 \%$ bovine serum albumin. FFA and antipyrine were added to maternal circulation and their appearance in fetal venous circulation was recorded. FFA clearance ratio $=$ ratio of FFA clearance to antipyrine clearance. Note logarithmic scale on vertical ordinate.
Table 4. Relation of transfer rates to lipid solubility and protein binding

\begin{tabular}{lcccc}
\hline & \multicolumn{3}{c}{ Partition $^{1}$} & \\
\cline { 3 - 4 } $\begin{array}{l}\text { Free fatty } \\
\text { acid }\end{array}$ & $\begin{array}{c}\text { Transfer } \\
\text { rate }\end{array}$ & $\begin{array}{c}\text { Hexane: } \\
\text { buffer }\end{array}$ & $\begin{array}{c}\text { Toluene: } \\
\text { buffer }\end{array}$ & $\begin{array}{c}\text { Protein binding } \\
\mathrm{K}_{\mathbf{a}}{ }^{\prime}{ }^{2} \mathrm{M}^{-1}\end{array}$ \\
\hline C 4 & 0.44 & 0.0002 & 0.0003 & \\
C 6 & 0.61 & 0.001 & 0.003 & $1.48 \times 10^{43}$ \\
C 8 & 0.50 & 0.003 & 0.02 & $3.36 \times 10^{43}$ \\
C 10 & 0.22 & 0.04 & 0.34 & $1.03 \times 10^{53}$ \\
C 12 & 0.16 & 0.62 & 5.2 & $1.56 \times 10^{54}$ \\
C 14 & 0.11 & 12.3 & 101.6 & $2.21 \times 10^{64}$ \\
C 16 & 0.04 & 27.2 & 349.8 & $6.78 \times 10^{64}$ \\
Antipyrine & 1.00 & 0.002 & 0.31 & 0 \\
\hline
\end{tabular}

${ }^{1}$ Partition of organic solvent to buffered salt solution, expressed as a ratio.

${ }^{2}$ Only $\mathrm{K}_{\mathrm{a}}{ }^{\prime}$ is presented; however, the several available binding sites maintain their relative values for each of the free fatty acids.

${ }^{3}$ Human serum albumin (1)

${ }^{4}$ Bovine serum albumin (2).

\section{DISCUSSION}

The development of an in vitro perfusion system of human placenta with a "maternal" and "fetal" circulation has permitted the study of the effect of protein binding on the transfer rates of FFA under carefully controlled conditions. Transfer rates have been reported as the clearance ratios of FFA to antipyrine to reduce variability of results among different experiments $(2,3)$, as discussed previously, and to permit comparison with previous data from this laboratory. The design of the present series of experiments depends almost entirely, however, on intraexperimental comparisons. By leaving the maternal and fetal circulations "open," that is by not recirculating either perfusate, transfer rates from maternal to fetal circulation could be measured accurately without the complication of significant transfer in the reverse direction. It should be emphasized that the effect of protein binding on the transfer rate of FFA across the placenta was measured. The effect of protein binding on the relative levels in maternal and fetal concentrations at equilibrium was not the subject of the present investigation. Similarly, the rates of transfer into the placenta, or "placental membrane," may have influenced the results, as indicated below, but it is the rate of transfer across the placenta that was measured.

The two FFA, C 6 and C 10, were selected for study because they are soluble in buffered salt solution at the concentrations that have been used in previous studies of FFA, and yet are bound to serum albumin when albumin is added to the perfusate. It was therefore possible to design experiments comparing rates of transfer with and without protein binding. The differences in the protein association constants for $\mathrm{C} 6$ and $\mathrm{C} 10$ provided further insights into the effect of protein binding on transfer rate. The difference in molecular size between the two FFA probably contributed little to the observed differences in transfer rates (9), and has been ignored as a factor in the following considerations.

The clearances for $\mathrm{C} 6$ were calculated from the total radioactivity transferred. In some experiments, as much as $30 \%$ of the transferred radioactivity was identified as polar metabolites of $C 6$. In the context of the present studies, it was considered preferable to use total radioactivity to calculate clearance, on the premise that transport into the placenta was a necessary precondition to metabolism. The effect of protein binding on $\mathrm{C} 6$ therefore includes transfer and metabolism. With $\mathrm{C} 10$ there was little conversion to polar metabolites, and the results indicate the effects on transfer alone. The very rapid conversion of the shorter FFA raises the interesting question of a possible placental role in the alteration of maternal nutrients before fetal consumption. 
The transfer rate of $\mathrm{C} 10$ through the placenta, in the absence of protein in either circulations, was slower than for C 6 . Previous data on the relation of membrane permeability of compounds to their lipid solubility $(5,7,9)$ might have suggested the reverse result. This apparent inconsistency would be resolved if increased lipid solubility were associated with increased binding within the placenta, thereby reducing the rate of transfer across the placenta. Attempts to demonstrate such differences in binding between $\mathrm{C} 10$ and $\mathrm{C} 6$ using isolated villi of placenta were obstructed by the rapid conversion of $\mathrm{C} 6$ to more polar metabolites.

Protein binding in the maternal circulation retarded the transfer of the two FFA significantly, the effect being more pronounced with $\mathrm{C} 10$ (Table 1). The availability of protein for binding in the fetal circulation, in excess of that in the maternal circulation, accelerated the transfer rate. The effect was again more pronounced with $\mathrm{C} 10$, the transfer rate actually exceeding that of antipyrine (Table 2). With equivalent amounts of BSA in the maternal and fetal circulations, which more closely simulates in vivo conditions, the rate of transfer of $\mathrm{C} 10$ remained considerably lower than that observed with buffered salt solutions. The acceleration effect of fetal albumin on transfer rate did not cancel the retardation effect of maternal albumin (Table 3). The results with C 6 were more variable. In each type of study the results were more striking with $\mathrm{C} 10$ than with $\mathrm{C} 6$, presumably because of the higher protein binding association constant.

The transfer rates of diffusible materials across membranes is determined by the diffusion pressure which is dependent, in part, on differences in concentration of physically dissolved material on both sides of the membrane. The retardation in transfer rate observed as a result of protein binding in the maternal circulation may be attributed to the decrease in concentration of the physically dissolved or unbound FFA. However, the observed transfer rate exceeded that which would have been expected from the concentration of the unbound fraction as determined by equilibrium dialysis. This is particularly evident with C 10 (Table 1), for which protein binding reduced the unbound fraction to $7 \%$ of the initial concentration and transfer rates approximated $20 \%$ of that observed without BSA. Either a rapid release of FFA from albumin into plasma during circulation through the placenta occurs or there is direct release of FFA from albumin to the placenta.

The insolubility of the longer chain FFA in water solutions prevents conducting similar investigations on the effects of protein binding. However, certain extrapolations appear to be reasonable. With increasing chain length of the FFA, the transfer rate rapidly falls and protein binding increases (Table 4). In view of the observations with C 6 and $C 10$, a reasonable deduction is that the changes in transfer rate are at least partly the result of protein binding, and it is likely that protein binding is the major factor. There is, however, no simple mathematical relation between transfer rates and the fraction bound as determined by equilibrium dialysis or with the association constants as reported in the literature. A possible explanation is that both factors represent equilibrium constants, whereas protein binding should be considered in dynamic terms involving rates of release and rates of binding. It is also possible that factors in addition to protein binding contribute to the results.

It should be noted that the partition coefficients of the FFA (Table 4) were measured with trace concentrations because of the limited water solubilities of the long chain FFA. They were not measured at the concentrations used in the perfusion studies. However, they do provide a measure of a physical characteristic that has had value in determining permeabilities of other compounds through other membranes (9). As an indicator of protein binding, only $\mathrm{K}_{a}^{\prime}$ (Table 4 ) is presented, although other association constants are effective at the concentrations of FFA that were studied. $\mathrm{K}_{\mathrm{a}}{ }^{\prime}$ appeares to provide a reasonable measure of the overall protein binding of these compounds. The equilibrium constants were measured at the concentrations used in the perfusion experiments.
Although circulating albumin serves to reduce the placental transfer of the medium and short chain FFA, it may make available to the fetus more of the natural long chain FFA. Palmitic acid is so insoluble in buffered salt solution that even trace amounts $(0.4 \mu \mathrm{g} / \mathrm{ml}$ buffer $)$ failed to equilibrate across a dialysis membrane, suggesting aggregation of the material. The amount of palmitic acid that could be delivered in solution in buffer is considerably less than was transferred from albumin-containing perfusate (3)

In reviewing the relation of chain length to transfer rate, it has been noted that progressive shortening of the chain from $\mathrm{C} 16$ to $\mathrm{C}$ 8 is associated with a logarithmic increase in transfer rate (Fig. 1). The curve flattens at $C 6$ and there is a small but consistent reduction in transfer rate of $\mathrm{C} 4$. It appears that another characteristic of FFA emerges as significant in controlling transfer rate at $\mathrm{C} 6$, and that it becomes predominant at $\mathrm{C} 4$. Among the known factors, the most likely candidate is the increasing water solubility of the short chain FFA (Table 4). Our current concepts of membrane composition are consistent with the observation that hydrophilic compounds must use a more restrictive "polar" route in penetrating membranes. This explanation is complicated by the rapid metabolism of the short chain FFA, discussed above. Reinvestigation with nonmetabolizable compounds would be necessary to confirm this suggestion.

Review of the behavior of antipyrine provides some support for this interpretation. Antipyrine is rapidly transferred across biological membranes, including the placenta, so that the amount transferred is determined by circulating rather than membrane factors. Because its transfer rate reflects hemodynamic factors, which may vary from study to study, it has served as a useful baseline in measuring the performance of other materials. The rapid diffusion rate of antipyrine may be explained by the two chemical characteristics emphasized in the present study. It is not protein bound, thus avoiding the restrictive effect of circulating albumin, and possibly of binding within the placenta. Its lipid solubility, as indicated by partition between buffer and organic solvents (Table 4), is in the range of that for $\mathrm{C} 10$ and $\mathrm{C} 8$, and above that of $\mathrm{C} 6$ where flattening of the curve of transfer rates (Fig. 1) suggests impedance as a result of water solubility.

\section{SUMMARY}

The effect of protein binding on the rate of placental transfer of hexanoic and decanoic acids was investigated in an in vitro perfusion system of human placenta. The addition of serum albumin to maternal perfusate reduced the rates of transfer from maternal to fetal circulations. If albumin was also added to the fetal perfusate, the retarding effect of maternal serum albumin was reduced but not eliminated. Addition of albumin to the fetal perfusate only accelerated transfer. The results of these studies and those of a previously reported study of a series of FFA (2) indicate that protein binding is a major determining factor on rates of transfer for this class of compounds.

\section{REFERENCES AND NOTES}

1. Ashbrook, J. D., Spector, A. A., and Fletcher, J. E.: Medium chain fatty acid binding to human plasma albumin. J. Biol. Chem., 247: 7038 (1972)

2. Dancis, J., Jansen, V., Kayden, H. J., Bjornson, L., and Levitz, M.: Transfer across perfused human placenta. III. Effect of chain length on transfer of free fatty acids. Pediat. Res., 8: 796 (1974).

3. Dancis, J., Jansen, V., Kayden, H. J., Schneider, H., and Levitz, M.: Transfer across perfused human placenta. II. Free fatty acids. Pediat. Res., 7: 192 (1973)

4. Dancis, J., Money, W. L., Springer, D., and Levitz, M.: Transport of a mino acids by placenta. Amer. J. Obstet. Gynecol., 101: 820 (1968).

5. Donahedian, R. K., and Karmen, A.: Fatty acid transport and incorporation into human erythrocytes in vitro. J. Clin. Invest., 46: 1017 (1967).

6. Schneider, H., Panigel, M., and Dancis, J.: Transfer across the perfused human placenta of antipyrine, sodium and leucine. Amer. J. Obstet. Gynecol., 114:822 (1972).

7. Spector, A. A., and Brenneman, D. E.: Effect of free fatty acid structure on binding to rat liver mitochondria. Biochim. Biophys. Acta, 260: 433 (1972) 
8. Spector, A. A., John, K., and Fletcher, J. E.: Binding of long-chain fatty acids to bovine serum albumin. J. Lipid Res., 10: 56 (1969).

9. Wright, E. M., and Diamond, J. M.: Patterns of non-electrolyte permeability. Proc. Roy. Soc. Ser. B., 172: 227 (1969).

10. State College, $\mathrm{Pa}$.

11. Boston, Mass.

12. St. Louis, Mo.

13. We wish to thank Dr. William Rosner for valuable discussion and advice.
14. Dr. J. Dancis is a Career Investigator, National Institute of Child Health and Development, National Institutes of Health, Bethesda, Md.

15. This study was supported by Grants nos. HDO-0462 and CA 02071, National Institutes of Health, Bethesda, Md.

16. Requests for reprints should be addressed to: J. Dancis, M.D., Department of Pediatrics, New York University, Medical Center, School of Medicine, 550 1st Ave., New York, N. Y. 10016 (USA).

17. Accepted for publication August 15, 1975

\title{
Behavioral and Biochemical Correlates of Diet Change in Phenylketonuria
}

\author{
V. ELVING ANDERSON ${ }^{(60)}$ AND FELICIA S. SIEGEL \\ Dight Institute for Human Genetics, University of Minnesota, Minneapolis, Minnesota, USA
}

HEINZ H. BRUHL

Faribault State School and Hospital, Faribault, Minnesota, USA

\section{Extract}

The investigation was designed to explore the use of tests tapping reversible aspects of behavior and performance and to find out whether these data can be correlated with concurrent metabolic changes in different dietary phases. The four subjects had classic phenylketonuria, diagnosed on the basis of a high level of serum phenylalanine on a regular diet, and severe mental retardation. Three types of diet were used: the general institutional diet, a low phenylalanine diet, and a low phenylalanine diet with added L-phenylalanine. A position discrimination and reversal task was used. Blood samples were taken every week on the day before psychological testing, and one 24-hr urine sample was collected during each dietary phase.

In subjects $I$ and $I I$ performance deteriorated upon elevation of the serum phenylalanine level, but these changes were transient only, thus showing an adaptation to the effects of the high serum phenylalanine level.

Subject $I I I$ showed increased response latencies (slower test responses) during high phenylalanine diet phases and faster responses while on a low phenylalanine diet. The correlation between response time and phenylalanine level is highly significant $(r=0.86$, $P<0.001$ ).

On the low phenylalanine diet subject $I V$ 's responses were fast and her performance was very stable, which contrasted with erratic performance during the high phenylalanine phases. Calculations show a significant association with phenylalanine level, both for response time $(r=0.47, P<0.05)$ and for variability in response time within each session $(r=0.46, P<0.05)$.

Biochemical variability was observed in metabolic responses to phenylalanine loading, especially in the excretion of tryptophan metabolites.

\section{Speculation}

A simultaneous analysis of biochemical and behavioral parameters in sufficient detail to permit the detection of individual variability is shown to be feasible. Further studies of a similar nature on a larger scale should help to achieve a more precise understanding of the biochemical processes in the nervous system which are responsible for the behavioral changes.

Clinical observations $(9,18,19,55,56)$ suggest that phenylketonuria (PKU) produces two effects on the individual: (1) a permanent effect upon the developing brain, and (2) "toxic" effects upon somatic and central nervous system functions which are responsive to changes in the level of phenylalanine intake. Menkes (38) suggested that the reversible signs (such as eczema, hair pigment, muscular rigidity, hyperactivity, irritability, EEG abnormalities, and seizures) are associated with reversible competitive enzymatic inhibitions effected by the excessive amounts of phenylalanine and related compounds; whereas the irreversible signs (such as low IQ) result from structural abnormalities of the central nervous system (demyelination, spongy degeneration, gliosis) connected with alterations of proteins and lipids in the white matter.

Measurements of $1 \mathrm{Q}$ have been used to follow intellectual development on a low phenylalanine diet $(17,21,31)$ to determine when the special diet may be discontinued $(2,23,25,47)$, and to estimate extent of permanent brain damage (29); but such measures are relatively insensitive to any reversible effects of dietary changes in the older child with PKU.

The present investigation was designed to explore the use of tests tapping these reversible aspects of behavior and performance and to find out whether these data can be correlated with concurrent metabolic changes in different dietary phases $(5,46)$. In view of the exploratory nature of the study and the possibility of individual variability in response, we used a small number of subjects (Ss) but a large number of test sessions and trials per subject.

The use of institutionalized subjects with PKU has many obvious advantages for establishing a base rate of performance, for controlling diet, and for sampling blood and urine. The major 